\title{
IMPLEMENTASI PENDIDIKAN KARAKTER BERBASIS MODERASI BERAGAMA PADA JENJANG PENDIDIKAN ANAK USIA DINI
}

\section{IMPLEMENTATION OF RELIGIOUS MODERATION LEARNING AT EARLY CHILDHOOD EDUCATION LEVEL}

\author{
Mardan Umar ${ }^{1}$, Feiby Ismail ${ }^{*}$, Nizma Syawie ${ }^{2}$ \\ ${ }^{1}$ IAIN Manado, Jl. SH. Sarundajang, Kawasan Ring Road I Manado, Sulawesi Utara \\ ${ }^{2}$ Raudhatul Athfal Khotimah, Jl.17 Agustus,Manado, Kompleks Kantor Kementerian Agama Provinsi Sulawesi Utara \\ email: feibyismail@iain-manado.ac.id
}

Naskah Diterima: 14 April 2020; Direvisi: 3 Mei 2020; Disetujui: 16 Desember 2020

\begin{abstract}
The implementation of character education based on religious moderation for children should begin from the beginning at a golden age, because early childhood is the right time to provide a moderate character foundation in accordance with Islamic values, especially in muslim minority communities or communities. This study examines the implementation of character education based on religious moderation in early childhood, especially in kindergarten/RA Manado city which is a muslim minority area as well as factors that affect it.. This study uses a qualitative approach. Data collection techniques were obtained by observation, interview, and documentation. The results showed that the implementation of character education based on religious moderation in early childhood in minority areas is focused on three aspects, namely: 1) Strengthening of Aqidah; 2) Moral/Akhlak Education; and 3) Fostering Value of Tolerance. These three focuses are implemented through learning, habituation and role models. Factors that influence of the child's character building is environmental factors, teachers, support from parents and school committees, and the foundation support.
\end{abstract}

Keywords: Early childhood; Moderate; Minority; Raudhatul Athfal

\begin{abstract}
Abstrak
Implementasi pendidikan karakter berbasis moderasi beragama pada anak harus dimulai sejak awal pada usia emas, karena usia dini adalah masa yang tepat untuk memberikan landasan karakter moderat yang sesuai dengan nilai-nilai Islam, khususnya di daerah atau lingkungan masyarakat minoritas muslim. Penelitian ini mengkaji tentang implementasi pendidikan karakter berbasis moderasi beragama pada anak usia dini khususnya di TK/RA Kota Manado yang merupakan daerah minoritas muslim serta faktor-faktor yang mempengaruhinya.. Penelitian ini menggunakan pendekatan kualitatif. Teknik Pengumpulan data diperoleh dari observasi, wawancara dan dokumentasi. Hasil penelitian menunjukkan bahwa implementasi pembelajaran moderasi beragama pada anak usia dini di daerah minoritas difokuskan pada tiga aspek yaitu: 1) Penguatan Aqidah; 2) Pendidikan Akhlak; dan 3) Pembinaan Nilai Toleransi. Ketiga fokus ini diimplementasikan melalui program pembelajaran, pembiasaan dan pemberian teladan. Faktor-faktor yang mempengaruhi pembentukan karakter moderat pada anak yaitu: faktor lingkungan, faktor guru, dukungan orang tua dan Komite sekolah serta pihak Yayasan.
\end{abstract}

Kata kunci: Anak usia dini; Moderasi; Minoritas; Raudhatul Athfal. 


\section{PENDAHULUAN}

Pendidikan karakter dan watak anak sejak usia dini akan memberikan dampak yang kuat bagi perkembangannya. Para ahli sepakat bahwa program pendidikan karakter memiliki efek positif pada pengembangan karakter dan keberhasilan akademik (Katilmis, A., Eksi, H. \& Ozturk, 2011). Kedudukan karakter sangat penting apalagi jika disandingkan dengan kecerdasan."Intellegence plus character that is the true aim of education". Kecerdasan plus karakter, itulah tujuan yang benar dari pendidikan (Majid \& Andayani, 2010), karena pintar saja tidak cukup, tetapi harus pula berperilaku dan berkarakter baik (Purwanto, Qowaid, Ma'rifataini, \& Fauzi, 2019). Seperti yang dikemukakan juga bahwa pendidikan memiliki tanggung jawab terhadap pembentukan karakter anak (Almerico, 2014). Hal ini mengindikasikan bahwa pendidikan sejatinya tidak hanya aspek pengetahuan saja tetapi juga memfokuskan pada aspek karakter termasuk perkembangan emosional dan spiritual anak seperti sikap moderat dalam beragama.

Penanaman karakter anak yang kuat, harus sudah dimulai sejak awal pada usia dini (Juanda, 2019), sebab usia dini adalah fase keemasan dalam perkembangan anak (golden age). Dalam masa ini anak membutuhkan stimulus dan pengasuhan yang positif untuk pembentukan karakter yang baik (Rosyadi, 2013). Usia dini ketika anak mulai mengenal dunia di sekitarnya merupakan waktu yang tepat untuk memberikan landasan karakter yang baik pada anak.

Pendidikan Anak Usia Dini (PAUD) memiliki peranan penting dalam pembangunan bangsa karena sebuah peradaban besar terbentuk dari proses pendidikan sejak kecil. Sehingga proses awal terbentuknya suatu generasi akan menentukan masa depan suatu bangsa. Usia dini (2 sampai 7 tahun) merupakan saat penting bagi anak dalam menentukan arah hidup dan kemampuan dalam bersosialisasi dengan lingkungan sekitar (Gunawan, 2017). Pada lingkungan masyarakat majemuk sikap dan karakter moderat sangat penting bagi anak. Kementerian Agama (2019) menyebutkan makna moderat dalam beragama yaitu percaya diri dengan esensi ajaran agama yang dipeluknya, yang mengajarkan prinsip adil dan berimbang.

Pendidikan Anak Usia Dini sebagai bagian dari sistem pendidikan memegang peran sangat urgen dalam rangka meletakkan dasardasar pembelajaran sosial dan emosional yang berguna bagi perkembangan anak serta mempengaruhi perkembangannya secara positif (Durlak, Weissberg, Dymnicki, Taylor, \& Schellinger, 2011). Oleh sebab itu, pendidikan karakter di Lembaga Pendidikan Anak Usia Dini perlu menekankan kebiasaan sehari-hari dengan karakter yang positif. Dengan kata lain, karakter yang ditanamkan pada usia dini perlu dimasukkan dalam kegiatan pembelajaran anak sehari-hari (Kemendiknas, 2012). Demikian pula program lain seperti Sekolah Ramah Anak yang dapat meningkatkan karakter anak usia dini secara positif (Nuraeni, Andrisyah, \& Nurunnisa, 2019).

Perkembangan kemampuan anak pada usia dini khususnya untuk perkembangan motoriknya sangat pesat. Pada usia 3-5 tahun ditandai dengan usaha untuk mencapai kemandirian dan sosialisasi. Tahapan sangat penting bagi kehidupan selanjutnya, pada masa awal kehidupan dimulai kira-kira usia 3 tahun anak mulai mampu untuk menerima keterampilan dan pelajaran sebagai dasar-dasar pembentukan pengetahuan dan proses berpikir. Sehingga dalam pembelajaran anak usia dini perlu mendapatkan perhatian dari segi perkembangan jasmani dan rohaninya (Rahman, 2002).

Undang-Undang Nomor 20 tahun 2003 Bab I Pasal 1 ayat 14 telah menyebutkan bahwa: "Pendidikan anak usia dini adalah suatu upaya pembinaan yang ditujukan kepada anak sejak lahir sampai dengan usia enam tahun yang dilakukan melalui pemberian rangsangan pendidikan untuk membantu pertumbuhan dan perkembangan jasmani dan rohani agar anak memiliki kesiapan dalam memasuki pendidikan lebih lanjut" (Undang-Undang Sistem Pendidikan Nasional, 2003).

Sejalan dengan bunyi Undang-Undang bahwa mendidik dan membangun manusia Indonesia berarti mempersiapkan setiap anak bangsa untuk menjadi warga negara Indonesia yang bertanggung jawab dan mampu mewujudkan masyarakat yang adil dan makmur 
berdasarkan Pancasila. Membangun sambil mendidik, bahkan dapat dikatakan bahwa membangun adalah mendidik. Dalam pendidikan ini lembaga sekolah memegang peranan penting. Pendidikan anak usia dini sebagai program (formal) merupakan hal yang baru di masyarakat, meski secara faktual sudah dilaksanakan. Pendidikan Anak Usia Dini semula adalah pendidikan di jalur informal yang dilaksanakan di dalam keluarga. Dengan semakin sibuknya orang tua serta kemajuan pendidikan, merupakan alasan dilembagakannya pendidikan anak usia dini dalam lembaga pendidikan yang formal seperti Taman Kanak-kanak (TK) dan Raudhatul Athfal (RA) serta lembaga pendidikan non formal (Taman Penitipan Anak, Play group/Kelompok bermain, dan sejenisnya).

Mencermati uraian di atas, dapat dipahami bahwa pendidikan nasional menginginkan manusia Indonesia menjadi manusia yang memiliki ilmu pengetahuan, sikap dan karakter serta keterampilan dalam hidup bermasyarakat, berbangsa dan bernegara. Dalam konteks Indonesia sebagai negara majemuk, maka karakter moderat sangat penting diberikan pada anak. Semua kecakapan yang dimiliki harus senantiasa dilandasi dengan karakter yang baik, seperti sopan santun, kejujuran, disiplin dan kepedulian terhadap sesama, pribadi yang damai dan moderat. Sehingga akan menjadi fondasi yang mendasari setiap gerak kehidupan manusia Indonesia. Salah satu upaya yang dapat dilakukan adalah dengan penanaman karakter melalui pendidikan agama Islam (Ismail, 2018)

Terminologi Islam menyebutkan karakter dengan istilah akhlaqul karimah atau akhlak yang mulia. Akhlaqul karimah adalah suatu sifat, tabiat dan perilaku yang menunjukan adanya hubungan baik dengan Allah dan sesama makhluk yang didasari oleh nilai-nilai Islam. Untuk melekatkan dengan ajaran Islam, maka karakter ini dapat disebut sebagai karakter Islami. Karakter Islami adalah prilaku, sifat, tabiat, akhlak yang dilandasi oleh nilai-nilai Islam yang bersumber dari al-Quran dan Hadis Nabi SAW (Yuliharti, 2018). Mengingat pentingnya akhlak bagi anak, maka orang tua perlu mempertimbangkan aspek akhlak dalam pendidikan anaknya (Khamid, 2019). Dalam kondisi lingkungan yang mendukung, maka penanaman karakter akan dapat diterapkan dengan baik, namun bagaimana jika lingkungan sekitarnya seperti lingkungan keluarga maupun lingkungan sosial adalah wilayah non muslim atau umat Islam sebagai kaum minoritas. Tentu hal ini akan menjadi tantangan tersendiri, sebagaimana yang dihadapi di Kota Manado.

Implementasi pendidikan karakter moderasi beragama tentu sangat penting dalam memberi pemahaman dan wawasan sejak jenjang pendidikan anak usia dini. Menurut Kementerian Agama (2019) dalam buku Moderasi Beragama, disebutkan bahwa karakter moderasi meniscayakan adanya keterbukaan, penerimaan dan kerjasama antar kelompok yang berbeda, termasuk suku, etnis, budaya dan agama. Sehingga bagi anak didik yang diberikan pemahaman tentang moderasi beragama akan mampu menempatkan diri dengan baik dalam masyarakat yang majemuk.

Berdasarkan uraian sebelumnya, maka penelitian ini dianggap penting untuk mengkaji tentang proses implementasi pendidikan karakter berbasis moderasi beragama pada anak usia dini di daerah minoritas muslim khususnya di TK/RA yang ada di kota Manado dan faktorfaktor apa yang mempengaruhinya?.

Penelitian ini memfokuskan pada pendidikan karakter berbasis moderasi beragama di lembaga pendidikan anak usia dini yang ada di Manado dengan mengambil lokasi pada tiga (3) Taman Kanak-kanak (TK)/ Raudhatul Athfal (RA), yaitu RA Karakter Assalaam Manado, RA Ar Rahmah Manado, dan TK YAPIM Manado. Penelitian ini bertujuan untuk mendeskripsikan dan menganalisis proses implementasi pendidikan karakter pada anak di TK/RA di Kota Manado dan faktor-faktor yang berpengaruh dalam pendidikan karakter di Kota Manado.

\section{METODOLOGI}

Penelitian ini menggunakan pendekatan kualitatif, dengan fokus masalah yaitu implementasi pendidikan karakter berbasis moderasi beragama di daerah minoritas muslim. Penelitian ini merupakan penelitian lapangan yang menitikberatkan pada proses implementasi pendidikan karakter berbasis moderasi beragama pada tiga TK/RA yang ada 
di Kota Manado. Sumber data dalam penelitian ini adalah Kepala TK/RA dan para guru. Pengumpulan data dilakukan dengan observasi atau pengamatan terhadap objek yang diteliti. Selain itu, untuk mendapatkan konfirmasi terhadap hasil pengamatan dan memperdalam informasi, peneliti melakukan wawancara dengan informan seperti guru, dan orang tua. Peneliti juga menggunakan teknik dokumentasi dalam mengumpulkan data.

Peneliti menganalisis dan menguraikan temuan penelitian secara deskriptif dengan menggunakan alur model Milles \& Huberman yaitu: reduksi data, penyajian data, verifikasi dan penarikan kesimpulan (Miles \& Huberman, 1992). Peneliti juga menggunakan teknik triangulasi untuk pengecekan keabsahan data. Triangulasi yang digunakan adalah triangulasi teknik, triangulasi sumber dan triangulasi waktu. Hal ini dilakukan agar penelitian menapatkan data yang valid.

\section{HASIL DAN PEMBAHASAN}

\section{Implementasi Pendidikan Karakter di RA Assalaam Manado}

Pembentukan karakter di RA Assalaam Manado didasarkan pada program pembentukan perilaku melalui pembiasaan nilai-nilai agama dan moral. Penanaman nilainilai agama dan moral tersebut diharapkan membentuk sikap perasaan emosi agar menjadi anak yang mandiri dan disiplin. Untuk mewujudkan tujuan TK/RA dan merealisasikan program pembelajaran maka RA Assalaam berpatokan pada tema-tema pembelajaran dengan alokasi waktu yang telah disusun dan direncanakan.

Pelaksanaan proses pembelajaran di TK/RA Assalam didasarkan pada program yang telah dicanangkan dari tahun ke tahun. Secara umum program TK/RA terbagi atas program internal dan eksternal yang dapat diuraikan dalam tabel 1 .

Tabel 1. Program RA Assalaam

\begin{tabular}{lll}
\hline \multirow{2}{*}{ Program Unggulan } & \multicolumn{2}{c}{ Program Pembinaan Karakter } \\
\cline { 2 - 3 } & \multicolumn{1}{c}{ Internal } & \multicolumn{1}{c}{ Eksternal } \\
\hline Bahasa Inggris & Pembelajaran & Kunjungan \\
& Berbasis Karakter & Belajar \\
\hline Bahasa Arab & Pembiasaan & Darmawisata \\
\hline Komputer & Pemberian Teladan & Kerjasama \\
\hline
\end{tabular}

Kegiatan Pembelajaran di sekolah ini berlangsung sejak hari senin sampai kamis dengan berdasarkan pada kurikulum berbasis kompetensi dan SKH/SKM dari Dinas Pendidikan Nasional dan Kementerian Agama. Kegiatan belajar diawali dengan jurnal pagi dan kegiatan Sentra. Penelitian Iswantiningtyas dan Wulansari menyebutkan bahwa pembelajaran Model Sentra tepat digunakan dalam pembentukan karakter anak usia dini (Iswantiningtyas \& Wulansari, 2019).

Kegiatan pembelajaran karakter tidak hanya menyasar pada aspek pengetahuan dan karakter yang bersifat universal. Para guru di RA Assalaam juga mengupayakan pembentukan karakter melalui penanaman nilai-nilai Islami seperti penguatan Aqidah, ajaran ketauhidan dan latihan Ibadah. Kegiatan hari Jum'at diadakan praktek shalat, praktek ibadah, membiasakan bacaan do'a sehari-hari.
Di samping itu, penanaman nilai-nilai keislaman pada anak dilakukan melalui ceramah agama yang disampaikan guru-guru atau penceramah, pembina lain seperti ustadz dan ustadzah. Adapula kegiatan Tadzkir yang melibatkan anak maupun orang tua. Kegiatan tadzkir untuk orang tua dilakukan dengan memanfaatkan waktu orang tua saat menunggu anaknya di sekolah. Pihak sekolah mengundang ustadz atau ustadzah untuk memberikan kajian Islami atau kegiatan tilawah Al-Qur'an.

\section{Pendidikan Karakter Berbasis Moderasi Beragama di RA Assalaam Manado}

Faktor lingkungan menjadi faktor yang sangat berpengaruh dalam implementasi pendidikan karakter pada anak di RA Assalaam Manado. Lingkungan sekolah yang berada dekat dengan gereja dan pemukiman umat Kristen juga menjadi salah satu hal yang diperhatikan. Meskipun RA Assalaam 
berdekatan dengan Panti Asuhan Assalam dan Pesantren Assalaam, namun penguatan aqidah tetap menjadi fokus dalam pendidikan anak. Untuk menanamkan karakter moderat pada anak didik di RA Assalaam, mereka juga diajarkan tentang sikap menghargai dan menghormati sesama manusia agar di masa datang, mereka terbiasa dengan sikap menerima perbedaan, menghargai dan menghormati pemeluk agama lain. Lingkungan yang majemuk dimanfaatkan guru untuk mengenalkan anak didik tentang adanya perbedaan di masyarakat. Keberadaan rumah ibadah agama lain di samping sekolah memberi keuntungan tersendiri dalam mengenalkan keragaman agama sehingga rumah ibadah menjadi laboratorium pembelajaran moderasi beragama.

Selain itu, faktor lingkungan keluarga juga menjadi penentu dalam penanaman karakter moderat pada anak. Dukungan orang tua selama anak berada di rumah sangat membantu guru dalam pembelajaran karakter di lingkungan sekolah.

\section{Implementasi Pendidikan Karakter di RA Ar Rahmah}

Pendidikan karakter pada anak usia dini di RA Ar Rahmah diintegrasikan dalam setiap pembelajaran dan lebih khusus pada hari jum'at di mana pembinaan difokuskan pada pembinaan nilai-nilai Islam seperti ibadah dan akhlak. Pada anak usia dini, pembinaan akhlak diutamakan pada sikap dan perilaku anak dalam lingkungan keluarga (menghormati orang tua dan saudara), serta di lingkungan sekolah (menghormati guru dan teman).

Hasil wawancara dengan guru RA Ar Rahmah diperoleh informasi bahwa pendidikan karakter pada anak usia dini dilakukan pada halhal sederhana sejak awal memasuki lingkungan sekolah. Beberapa hal yang diajarkan diantaranya memberikan salam, menjawab salam, mencium tangan orang tua dan guru, mengucapkan "terima kasih", memohon bantuan dengan diawali ucapan "tolong" dan "meminta maaf" jika melakukan kesalahan. Contoh perilaku sederhana seperti ini yang terus diusahakan menjadi kebiasaan anak dalam kehidupan sehari-harinya. Hal ini terlihat pada proses pembelajaran di RA Ar Rahmah.
Sesuai hasil observasi terlihat guru memberikan pembelajaran pada anak tentang sikap-sikap yang baik dan kemudian menjelaskan manfaatnya. Setelah itu, proses pembiasaan dalam aktifitas sehari-hari di lingkungan sekolah mulai dari masuk hingga pulang sekolah. Dalam pengamatan peneliti, proses pembiasaan di antaranya dengan kewajiban mengucapkan salam ketika masuk dan mencium tangan guru. Berbaris dengan rapi dan berjalan masuk ke kelas dengan teratur.

Lokasi RA Ar Rahmah Manado yang berada di dalam lingkungan Panti Asuhan Ar Rahmah dan Masjid Baiturrahim memberikan kemudahan bagi guru untuk membina sikap dan karakter anak. Misalnya ketika kegiatan keagamaan langsung difokuskan di masjid. Demikian pula ketika guru akan mengajarkan sikap membantu, menyayangi sesama, maka guru akan dengan mudah memberikan contoh pada anak-anak yatim yang ada di lokasi sekolah. Di sisi lain, lokasi yang tanpa pengawasan ketat ini, masih terbuka bagi setiap orang sehingga ada anak-anak dari luar panti yang sering masuk dan terkadang memberikan contoh yang tidak baik bagi anak.

Faktor keluarga cukup pendukung pendidikan karakter, seperti para orang tua yang membantu memberikan pembinaan di lingkungan keluarga sehingga memudahkan tugas guru untuk membentuk sikap dan akhlak anak.

\section{Pendidikan Karakter Berbasis Moderasi Beragama di RA Ar Rahmah Manado}

Sebagaimana RA Assalaam, letak RA Ar Rahmah juga berjarak sekitar 50 meter dari Gereja Yarden. Uniknya gereja ini berada di kampung Islam. Kondisi ini mengharuskan guru RA Ar Rahmah memberikan pemahaman tentang pentingnya moderasi beragama. Pendidikan karakter berbasis moderasi beragama dilakukan dengan metode ceramah, kisah dan keteladanan guru serta memanfaatkan media gambar yang tersedia di sentra pendidikan di lingkungan sekolah.

Anak didik dilatih untuk menerima adanya pemeluk agama lain di lingkungan sekitarnya. Guru mengajarkan tentang konsep ukhuwah insaniyah atau persaudaraan sesama manusia dalam ajaran Islam sebagai bentuk 
karakter Islami. Suka membantu, menghargai dan menghormati sesama makhluk Tuhan sebagai akhlak yang mulia. Proses pembelajaran dilakukan dengan metode ceramah, belajar dalam kelompok kecil yang berbeda dan pembiasaan dalam aktifitas bersama teman dalam bentuk sederhana, misalnya sikap mau berbagi mainan. Selain itu, pengalaman guru di RA Ar Rahmah sangat membantu proses pembelajaran di lingkungan yang majemuk dan heterogen seperti di RA Ar Rahmah.

\section{Implementasi Pendidikan Karakter di TK YAPIM Manado}

Pendidikan karakter anak di TK Yayasan Pendidikan Islam Manado (YAPIM) Manado didasarkan pada pembelajaran di TK YAPIM Manado yang terbagi atas aspek kegiatan pembelajaran siswa, yaitu: (1) Standar Kompetensi, (2) Implementasi kegiatan gugus di TK, (3) Kegiatan Pendidikan anak seutuhnya.

Tabel 2. Standar Pembelajaran TK YAPIM

\begin{tabular}{|c|c|c|}
\hline \multirow[b]{2}{*}{ Standar Kompetensi } & \multicolumn{2}{|c|}{ Hasil Belajar \% } \\
\hline & $\begin{array}{c}\text { Capaian } \\
\text { Kompetensi }\end{array}$ & Pengayaan \\
\hline \multicolumn{3}{|l|}{ Pembiasaan } \\
\hline - $\quad$ Moral dan nilai-nilai agama & $100 \%$ & - \\
\hline - Sosial, emosional dan kemandirian & $100 \%$ & - \\
\hline \multicolumn{3}{|l|}{ Kemampuan Dasar } \\
\hline - Berbahasa & $90 \%$ & $10 \%$ \\
\hline - Kognitif & $100 \%$ & - \\
\hline - Fisik / Motorik & $90 \%$ & $10 \%$ \\
\hline - Seni & $100 \%$ & - \\
\hline
\end{tabular}

Pendidikan karakter di TK YAPIM dilaksanakan melalui pembiasaan nilai-nilai agama, sosial, emosional dan kemandirian. Pada pencapaian standar kompetensi nilai-nilai tersebut mampu mencapai angka sempurna 100 $\%$. Hal ini terlihat dari hasil belajar anak maupun dalam pengamatan sikap anak dalam pergaulan di lingkungan sekolah dan di dalam kelas. Pembinaan karakter anak dari segi bentuk dan waktu dilaksanakan sebagai bagian dari pembinaan anak seutuhnya yang dilaksanakan melalui program pembentukan perilaku anak, penanaman nilai karakter yang dilakukan melalui kegiatan ibadah sholat dan mengaji, serta kegiatan seni dan lomba yang menekankan pada pembinaan sikap dan karakter anak seperti jujur, mandiri, berani, rendah hati, tanggung jawab, toleran dan lain-lain.

Berbeda dengan kedua TK/RA sebelumnya, TK YAPIM berada di lokasi pemukiman muslim yaitu Kampung Arab, namun berbatasan dengan kampung Cina (pecinan) dengan penduduk beragama Budha dan Khonghucu, lengkap dengan Klenteng sebagai tempat ibadahnya. Keadaan ini menjadikan guru di TK YAPIM juga menjadikan karakter Islami sebagai penguat pembelajaran bagi anak usia dini di sekolahnya.

Pembentukan karakter bagi anak di TK YAPIM didukung oleh faktor lingkungan di sekitar sekolah yang didominasi oleh pemeluk Islam keturunan Arab. Beberapa sudut jalan terdapat kalimat Toyyibah dan tulisan asma'ul husna yang terpajang di sepanjang jalan. Secara otomatis, anak menjadi terbiasa membaca kalimat Toyyibah dan Asma'ul Husna setiap hari. Dalam kaitan dengan pembiasaan sikap sehari-hari, guru membuat program pembelajaran yang menyenangkan bagi anak untuk mencontoh perilaku baik, seperti memberi salam, membantu sesama, berbagi mainan, menjaga kebersihan, serta melatih aktifitas sehari-hari lainnya seperti sikat gigi yang benar, dan lain-lain.

Pihak Pengurus Yayasan Islam Manado sangat menopang kegiatan pembelajaran anak di TK YAPIM dengan menyediakan kebutuhan fasilitas yang dibutuhkan. Menurut kepala sekolah, hal ini sangat penting dalam membantu pengembangan sekolah dan dalam pembinaan 
anak termasuk masalah karakter. Dukungan orang tua dan komite sekolah bagi pendidikan di TK YAPIM khususnya pembinaan karakter sangat mendukung program-program pembelajaran.

\section{Implementasi Pendidikan Karakter berbasis Moderasi Beragama pada Pendidikan Anak Usia Dini di Kota Manado}

Suatu tantangan tersendiri bagi lembaga pendidikan anak usia dini dalam mengimplementasikan pendidikan karakter di daerah minoritas muslim seperti di Manado. Meski demikian, kondisi ini menjadi sebuah keuntungan dalam pembelajaran berbasis moderasi beragama sebab lingkungan masyarakat yang majemuk secara langsung menjadi laboratorium pendidikan moderasi beragama. Pendidik dapat memanfaatkan kemajemukan masyarakat sebagai contoh nyata kehidupan masyarakat yang harmonis dalam perbedaan. Menerima perbedaan, menghormati dan menghargai sesama, serta mampu bertindak adil.

Hal ini sesuai dengan uraian Kementerian Agama (2019) dalam Buku Moderasi Beragama yang menyatakan bahwa moderasi beragama dapat dipahami sebagai cara pandang dan sikap adil dan di tengah serta seimbang pada pengamalan agama dan penghormatan pada praktik agama orang lain yang berbeda keyakinan.

Bagi masyarakat kota Manado, situasi dan kondisi berbeda dalam pengamalan ajaran agama adalah pemandangan yang biasa terlihat dalam aktifitas sosial. Sehingga perlu ada pendidikan karakter moderasi beragama sejak usia dini agar anak memiliki pemahaman yang benar tentang sikap beragama yang moderat.

Selain proses pembelajaran di sekolah, ada beberapa faktor yang ikut berpengaruh, seperti faktor lingkungan sekolah, lingkungan tempat tinggal, dan lingkungan bermain. Jika ditinjau dari program dan proses pembelajaran, struktur kegiatan pembelajaran TK/RA di Manado mengacu pada kurikulum yang ada. Berdasarkan tujuan pembelajaran di Raudhatul Athfal, ada dua tujuan yang ingin dicapai yaitu:

a. Tujuan Umum, yakni memperluas pelayanan dan dukungan pendidikan keagamaan bagi kelangsungan hidup anak serta meningkatkan pengetahuan, keterampilan, sikap orang tua dan masyarakat akan perkembangan anak.

b. Tujuan Khusus, yakni memberikan pelayanan pendidikan keagamaan, kesehatan gizi secara holistik dan integrasi bagi anak usia dini, memberikan pelayanan konsultasi dan informasi bagi masyarakat dan lembaga mengenai tumbuh kembang anak, memberikan pembinaan kepada pengelola program anak usia dini kepada masyarakat serta melaksanakan penelitian dan pengembangan pendidikan anak usia dini yang meliputi rangsangan intelegensi dan aspek agama.

Adapun program Pengembangan Kemampuan Dasar difokuskan pada empat hal yaitu: bahasa, kognitif, fisik motorik dan seni. Sedangkan untuk program pembentukan karakter (perilaku) yang mencakup nilai-nilai agama, nilai-nilai moral Pancasila dan sosial kemasyarakatan.

Nilai-nilai agama dapat disampaikan melalui pemahaman akan enam dunia makna yaitu; 1) Makna Simbolik meliputi bahasa, simbol, isyarat- isyarat, dan sebagainya; 2) Makna Empirik pengembangan kemampuan teoritis, fakta- fakta dan kenyataan tentang kehidupan beragama; 3) Makna Estetik meliputi nilai- nilai keindahan dalam agama; 4) Makna Sinoetik berkenaan dengan perasaan, kesan, penghayatan dan kesadaran yang mendalam akan nilai-nilai agama; 5) Makna Etik berkenaan dengan aspek-aspek moral, akhlak, perilaku yang luhur, dan tanggung jawab; dan 6) Makna Sinoptik yang berkaitan dengan makna yang mendalam mengenai hal - hal yang bernuansa spiritual (Umar, 2018).

Hasil penelitian menunjukkan bahwa implementasi nilai-nilai karakter berbasis moderasi beragama dalam pendidikan anak di RA Assalaam Manado, RA Ar Rahmah dan TK YAPIM menggunakan tiga pola yaitu pembelajaran, pembiasaan dan pemberian teladan. Pada awalnya pendidikan karakter dilakukan dengan proses pembelajaran di kelas, anak diajarkan sikap-sikap karakter yang baik. Anak dilatih untuk menghormati, menghargai, menyayangi, menerima perbedaan, sopan santun, rendah hati, tidak nakal dan tidak 
mengganggu teman, berbagi dengan sesama, menolong, budaya antri, dan lain-lain.

Tabel 3. Implementasi Sikap/Karakter di TK/RA

\begin{tabular}{|c|c|}
\hline Karakter Moderat & $\begin{array}{l}\text { Metode dan Implementasi dalam } \\
\text { Pembelajaran }\end{array}$ \\
\hline Taat Beribadah & Ceramah, Praktek \\
\hline Menghormati, Menghargai Sesama & Ceramah, Pembiasaan, Peneladanan \\
\hline Menerima Perbedaan, Toleran & Pembiasaan, Peneladanan \\
\hline Tolong menolong, Mau berbagi. & Pembiasaan, Latihan \\
\hline Sopan santun, Rendah Hati & Ceramah, Peneladanan. \\
\hline
\end{tabular}

Pada tabel 3 di atas, diuraikan karakter yang ditanamkan pada anak usia dini di TK/RA kota Manado. Dalam posisi sebagai kaum minoritas, maka penguatan Aqidah serta ketaatan beribadah menjadi karakter utama dan penting bagi keberhasilan belajar. Hasil penelitian Sulfemi membuktikan bahwa disiplin beribadah dapat meningkatkan hasil belajar anak (Sulfemi, 2018). Selanjutnya, penanaman karakter moderat melalui sikap menghormati dan menghargai, menerima perbedaan dan toleran, tolong menolong, mau berbagi, sopan santun, dan rendah hati. Sikap ini diharapkan akan menjadi bagian dari karakter yang dimiliki anak saat berinteraksi dengan lingkungannya yang heterogen. Implementasi dalam pembelajaran dilakukan dengan metode ceramah dan praktek yang didukung dengan latihan dan pembiasaan serta teladan dari guru dan orang tua.

Pembentukan karakter terdiri dari tiga aspek yang berkaitan yaitu moral knowing, moral feeling dan moral action atau moral behavior (Lickona, 1991). Sehingga pendidikan karakter anak usia dini diawali dengan pemberian pemahaman dan pengetahuan tentang sikap baik melalui proses pembelajaran, kemudian memperkuat pemahaman itu agar menjadi suatu keyakinan dan dihayati, serta dilakukan dalam aktifitas sehari-hari secara terus menerus agar menjadi kebiasaan.

Tahapan peneladanan diupayakan guru dengan memberikan teladan dan contoh sikap yang baik. Anak akan lebih mudah mencontoh dan mengikuti apa yang dilihatnya, apalagi itu berlangsung setiap hari. Para guru biasanya memberikan contoh ketika anak-anak akan beristirahat makan. Mereka berdiri di depan dan memberikan contoh antri menunggu giliran keluar ruangan dan kemudian mencuci tangan secara bergantian. Demikian pula contoh teladan lain yang ditunjukkan guru dengan membantu anak yang kesulitan dalam belajar atau melakukan suatu aktifitas di sekolah.

Meski demikian, ketiga proses ini tidak selamanya diawali dengan pemberian pengetahuan terlebih dahulu, bisa saja dilakukan dimulai dengan pembiasaan perilaku (habituasi), kemudian disusul dengan penanaman pemahaman tentang nilai karakter. Bagi anak usia dini, pembiasaan dalam setiap aktivitas sehari-hari sangat penting dalam pembentukan karakter. Oleh sebab itu, peran lingkungan sangat penting, baik lingkungan sekolah maupun lingkungan keluarga. Penelitian Hasanah \& Deiniatur menemukan bahwa terdapat hubungan inter-relasi antara setiap komponen yang berpengaruh dalam pendidikan karakter seperti sekolah dan masyarakat (Hasanah \& Deiniatur, 2018). Demikian pula Susanto yang menyatakan bahwa faktor lingkungan merupakan faktor yang sangat berpengaruh pada perkembangan dan perubahan sikap dan perilaku anak (Susanto, 2011). Di samping itu, dukungan orang tua sangat penting dalam keberhasilan pendidikan karakter secara holistik pada anak didik (Ulfah, 2019).

Proses pendidikan karakter di lingkungan pendidikan memiliki peran dan fungsi antara lain sebagai sarana untuk memimpin dan membimbing agar dapat mencapai pertumbuhan dan perkembangan jasmani dan rohani secara sempurna. Selanjutnya, pendidikan harus diarahkan untuk menjadikan anak didik memiliki sifat-sifat kemanusiaan dengan mencapai akhlaqul karimah yang sempurna (Nata, 2005). Untuk 
mencapainya diperlukan banyak faktor yang harus saling mendukung, termasuk di dalamnya peran guru dalam membangun karakter anak sejak dini yang meliputi empat hal, yaitu (1) pendidik, (2) panutan, (3) perancang pengembangan, dan (4) konsultan dan mediator (Maryatun, 2016). Oleh karena itu, peran guru dalam pendidikan karakter moderat juga perlu dioptimalkan sebagai pendidik yang responsif dengan keadaan dan mampu menyesuaikan pembelajaran dengan situasi dan keadaan daerah.

Sebagaimana fungsi pendidikan Raudhatul Athfal (RA) yaitu mengenalkan nilai-nilai keimanan, mengenalkan penanaman disiplin dan mandiri pada anak, menumbuhkan rasa percaya diri pada anak, mengenalkan anak dengan dunia sekitar, menumbuhkan sikap akhlaqul karimah, mengembangkan kemampuan berkomunikasi dan bersosialisasi, maka pembelajaran karakter di daerah minoritas perlu mengoptimalkan kemampuan anak sejak usia dini dalam hal sosialiasi dengan lingkungan yang heterogen, berbeda agama bukan menjadi penghalang bagi anak untuk berinteraksi namun dengan batasan-batasan yang jelas pada aspek keyakinan dan ibadah sesuai anjuran Islam.

\section{PENUTUP}

Berdasarkan hasil penelitian yang diperoleh dalam penelitian ini, maka dapat disimpulkan bahwa implementasi pendidikan karakter berbasis moderasi beragama di daerah minoritas muslim kota Manado khususnya di RA Assalaam Manado, RA Ar Rahmah dan TK YAPIM difokuskan pada tiga aspek yaitu: 1) Penguatan Aqidah; 2) Pendidikan Akhlak; dan 3) Pembinaan Nilai Toleransi. Ketiganya diupayakan melalui kegiatan pembelajaran di dalam kelas yang diintegrasikan dalam setiap materi pelajaran, pembiasaan (habituasi) dan peneladanan. Kemudian ditunjang dengan kegiatan di luar kelas terkait pembentukan perilaku menyangkut nilai-nilai moral dan agama. Sehingga dapat disimpulkan bahwa implementasi pendidikan karakter pada pendidikan anak usia dini dilaksanakan melalui tiga pola yaitu: program pembelajaran, pembiasaan dan pemberian teladan (contoh).

Faktor-faktor yang mempengaruhi pembentukan karakter anak usia dini di antaranya faktor lokasi dan lingkungan sekolah, faktor lingkungan keluarga. Kondisi masyarakat dan lingkungan yang majemuk dengan perbedaan agama menjadi keuntungan tersendiri dalam pembelajaran karakter moderat sehingga anak terlatih dalam menerima perbedaan. Terakhir, perlu ditegaskan bahwa pendidikan karakter sejatinya tidak hanya aspek pengetahuan tetapi juga memfokuskan pada perkembangan emosional dan spiritual anak khususnya di usia dini.

\section{UCAPAN TERIMAKASIH}

Terimakasih kami ucapkan kepada semua pihak yang berperan dalam proses penelitian ini. Khususnya kepada Kepala TK/RA dan seluruh guru di RA Assalaam Manado, RA Ar Rahmah Manado dan TK YAPIM Manado yang telah memberikan izin untuk melaksanakan kegiatan penelitian ini serta membantu memberikan infomasi yang dibutuhkan. Ucapan terima kasih juga disampaikan kepada tim editor Jurnal Edukasi yang telah memberikan saran, kritik, dan rekomendasi untuk perbaikan artikel ini.

\section{DAFTAR PUSTAKA}

Almerico, G. M. (2014). Building character through literacy with children's literature. Research in Higher Education Journal, 26.

Durlak, J. A., Weissberg, R. P., Dymnicki, A. B., Taylor, R. D., \& Schellinger, K. B. (2011). The Impact of Enhancing Students' Social and Emotional Learning: A Meta-Analysis of School-Based Universal Interventions. Child Development, 82(1), 405-432. https://doi.org/10.1111/j.14678624.2010.01564.x

Gunawan, R. (2017). The Role of Character Education for Early Children in Early Childhood Education Programs in Happy Kids Bogor Indonesia. Advances in Social Sciences, Education and Humanities Research (ASSEHR), 66(Yicemap), 2326. Atlantis Press.

Hasanah, U., \& Deiniatur, M. (2018). Character Education in Early Childhood Based on Family. Early Childhood Research 
Journal.

https://doi.org/10.23917/ecrj.v1i1.6578

Ismail, F. (2018). Pengembangan Karakter melalui Pendidikan Agama Islam. Jurnal Ilmiah Iqra'. https://doi.org/10.30984/jii.v7i2.608

Iswantiningtyas, V., \& Wulansari, W. (2019). Penanaman Pendidikan Karakter pada Model Pembelajaran BCCT (Beyond Centers and Circle Time). Jurnal Obsesi : Jurnal Pendidikan Anak Usia Dini, 3(1), 110-116.

https://doi.org/10.31004/obsesi.v3i1.106

Juanda, J. (2019). Pendidikan Karakter Anak Usia Dini melalui Sastra Klasik Fabel Versi Daring. Jurnal Obsesi: Jurnal Pendidikan Anak Usia Dini. https://doi.org/10.31004/obsesi.v3i1.126

Katilmis, A., Eksi, H. \& Ozturk, C. (2011). Efficiency of Social Studies Integrated Character Education Program. Educational Sciences: Theory \& Practice, 11(2), 36-50.

Kemendiknas. (2012). Pedoman Pendidikan Karakter Pada Usia Dini. Indonesia: Kementerian Pendidikan Nasional.

Kementerian Agama RI (2019). Moderasi Beragama, Jakarta: Badan Litbang dan Diklat Kementerian Agama RI.

Khamid, A. (2019). Nilai-nilai Pendidikan Akhlak Perspektif Imam Nawawi AlBantani Dalam Kitab Nashaih Al-'Ibad. POTENSIA: Jurnal Kependidikan Islam, 5(1), 29-43.

Lickona, T. (1991). Educating For Character, How Our Schools Can Teach Respect and Responsibility. New York: Bantam Books.

Majid, A., \& Andayani, D. (2010). Pendidikan Karakter dalam Perspektif Islam. Bandung: Insan Cita Utama.

Maryatun, I. B. (2016). Peran Pendidik PAUD dalam Membangu Karakter Anak. Jurnal Pendidikan Anak. https://doi.org/10.21831/jpa.v5i1.12370

Miles, M. B., \& Huberman, ;A Michael. (1992). An Expanded Sourcebook Qualitative
Data Analysis. In Archives of Gynecology and Obstetrics. https://doi.org/10.1007/BF02759913

Nata, A. (2005). Filsafat Pendidikan Islam, Jakarta: Gaya Media Pratama. Jakarta: Gaya Media Pratama.

Nuraeni, L., Andrisyah, A., \& Nurunnisa, R. (2019). Efektivitas Program Sekolah Ramah Anak dalam Meningkatkan Karakter Anak Usia Dini. Jurnal Obsesi : Jurnal Pendidikan Anak Usia Dini, 4(1), 20-29. https://doi.org/10.31004/obsesi.v4i1.204

Purwanto, Y., Qowaid, Q., Ma'rifataini, L., \& Fauzi, R. (2019). Internalisasi Nilai Moderasi Melalui Pendidikan Agama Islam di Perguruan Tinggi Umum. EDUKASI: Jurnal Penelitian Pendidikan Agama Dan Keagamaan, 17(2), 110-124. https://doi.org/10.32729/edukasi.v17i2.6 05

Rahman, H. S. (2002). Pendidikan Anak Usia Dini. Yogyakarta: PGTKI Press.

Rosyadi, R. (2013). Pendidikan Islam dalam Pembentukan Karakter Anak Usia Dini. Jakarta: PT. Rajagrafindo Persada.

Sulfemi, W. B. (2018). Pengaruh Disiplin Ibadah Sholat, Lingkungan Sekolah dan Intelegensi Terhadap hasil Belajar Peserta Didik mata Pelajaran Pendidikan Agama Islam. EDUKASI: Jurnal Penelitian Pendidikan Agama Dan Keagamaan, 16(2), 166-178. https://doi.org/10.32729/edukasi.v16i2.4 74

Susanto, A. (2011). Perkembangan Anak Usia Dini. Jurnal Golden Age, Hamzanwadi University.

Ulfah, M. (2019). Pendekatan Holistik Integratif Berbasis Penguatan Keluarga pada Pendidikan Anak Usia Dini Full Day. Jurnal Obsesi : Jurnal Pendidikan Anak Usia Dini, 4(1), 10-19. https://doi.org/10.31004/obsesi.v4i1.255

Umar, M. (2018). Pembinaan Kedamaian Hidup Beragama melalui Optimalisasi Pendidikan Agama. Jurnal Ilmiah Iqra'. https://doi.org/10.30984/jii.v10i1.588 
Republik Indonesia, (2003), Undang-Undang Sistem Pendidikan Nasional, No. 20 tentang Sistem Pendidikan Nasional. Indonesia.

Yuliharti, Y. (2018). Pembentukan Karakter
Islami Dalam Hadis dan Implikasinya Pada Jalur Pendidikan Non Formal. POTENSIA: Jurnal Kependidikan Islam, 4(2).

https://doi.org/10.24014/potensia.v4i2.59 18. 